\title{
The Evolution of Business Incubators: Comparing demand and supply of business incubation services across different incubator generations
}

\author{
Johan Bruneel ${ }^{\mathrm{a}, \mathrm{b}}$, Tiago Ratinho ${ }^{\mathrm{c}, *}$, Bart Clarysse ${ }^{\mathrm{a}, \mathrm{b}}$, Aard Groen ${ }^{\mathrm{c}}$ \\ a Imperial College Business School, Imperial College London, South Kensington Campus, London SW7 2AZ, UK \\ ${ }^{\mathrm{b}}$ Faculty of Economics and Business Administration, Ghent University, Hoveniersberg 24, 9000 Gent, Belgium \\ ${ }^{\mathrm{c}}$ Nikos, Dutch Institute for Knowledge Intensive Entrepreneurship, University of Twente, Postbus 217, 7500 AE Enschede, The Netherlands
}

\section{A R T I C L E I N F O}

Available online 3 December 2011

Keywords:

Business incubation

Business support

Entrepreneurship

\begin{abstract}
A B S T R A C T
Business incubators (BIs) have been established around the world to stimulate new business creation. Whilst it is accepted that incubation models have evolved, little is known about whether existing incubators have adjusted their value proposition to incorporate recent incubation paradigms or have simply remained operating as originally founded. We present data collected within seven BIs and their tenants regarding service provision and selection criteria. Our findings show that whilst BIs of all generations offer similar support services, tenants in older generation BIs make less use of the BI's service portfolio. We suggest this is a consequence of slack selection criteria and the absence of clearly defined exit policies. These results imply that older generation BIs should update their service portfolio while simultaneously imposing stricter selection criteria and introducing exit policies. Finally, we discuss the wider implications this raises for BIs' managers, prospective tenants and policy makers.
\end{abstract}

\section{Introduction}

Business incubators (BIs) are popular tools to accelerate the creation of successful entrepreneurial companies. There are about 900 BIs in the European Union (EC, 2002) and over 1400 in the US (Knopp, 2007), numbers showing a marked increase in recent decades. As BIs are often publicly funded (Lewis, 2001; OECD, 1999, 2010), this corresponds with a growing interest of policy makers in making BIs a central tool in economic rejuvenation programmes. BIs typically support new ventures in the hope they will later develop into self-sustaining, thriving companies. This support encompasses several dimensions such as office space, shared resources, business support, and access to networks (e.g. Barrow, 2001; Smilor and Gill, 1986).

Practitioner publications often claim the benefits of BIs (Lewis, 2010; NBIA, 2011). There is, however, little systematic evidence of BIs' efficacy in promoting job and wealth creation (Massey et al., 1992; Phan et al., 2005). Furthermore, research has found little or no evidence of BIs' contribution to university-industry interaction (Rothaermel and Thursby, 2005a, 2005b), innovation activity (Colombo and Delmastro, 2002), or firm performance (Peña, 2004). Hackett and Dilts (2004) suggest that this is a consequence of the recurrent absence of an adequate theoretical lens to

\footnotetext{
* Corresponding author.

E-mail addresses: j.bruneel@imperial.ac.uk (J. Bruneel), b.clarysse@imperial.ac.uk (T. Ratinho), tiago.ratinho@utwente.nl (B. Clarysse), a.j.groen@utwente.nl (A. Groen).
}

consistently analyse BIs' activities. We argue that understanding the evolution of BIs' value proposition over recent decades is vital to understand and assess their impact on incubated firms.

BIs became widespread in the 1980s, primarily as providers of office space, agglomerating companies under the same roof (Adkins, 2002; Lalkaka and Bishop, 1996). This value proposition evolved quickly during that decade when lack of business expertise became evident as a similarly important barrier to new firms' success. Throughout the 1990s, BIs expanded their value proposition beyond offering infrastructure, providing in-house business support services geared towards accelerating new firms' learning process (Lalkaka and Bishop, 1996). Recently, the value of these networks for new firms triggered a new type of BIs that include preferred access to networks as part of their value proposition (Hansen et al., 2000). Current BIs constitute the third generation of incubators typically focused on new technology-based firms (Aerts et al., 2007), in contrast to the first generation emphasizing real estate provision and the second generation including intangible services. Yet extant literature largely overlooks how this evolution of BIs' value proposition has affected service portfolios and management practices. Large scale and industry studies, for example, (EC, 2002; Knopp, 2007; OECD, 1997, 1999; Tornatzky et al., 2003) show differences in BIs' value proposition but fail to offer an explanation. Moreover, findings from previous studies including only first and/or second generation BIs may not necessarily apply to the current generation. Hence, our first research question: to what extent has the value proposition of first and second generation BIs evolved to meet that of the current 
generation? Arguably, differences between BIs' value propositions would only be observable if assessed by tenants themselves. Therefore, our second research question seeks to understand the extent to which the value proposition of each generation of BIs caters to their tenants' needs.

\section{Business incubators' value proposition}

Despite the relative maturity of BIs both as a practice and as a research field, a consensual definition for BIs is yet to be found (Table 1). In their comprehensive BI research overview, Hackett and Dilts (2004) state that a "business incubator is a shared office space facility that seeks to provide its incubatees (...) with a strategic, value-adding intervention system of monitoring and business assistance" (p. 57). This echoes the commonalities found between other definitions advanced by industry associations (NBIA, 2007; UKBI, 2007), large scale studies (EC, 2002; OECD, 1997) and in academic work (Aernoudt, 2004; Sherman and Chappell, 1998) (Table 1). In summary, BIs are property based

Table 1

Definitions of business incubation.

National Business Incubation Association (NBIA, 2007). Business incubation is a business support process that accelerates the successful development of start-up and fledgling companies by providing entrepreneurs with an array of targeted resources and services. These services are usually developed or orchestrated by incubator management and offered both in the business incubator and through its network of contacts. A business incubator's main goal is to produce successful firms that will leave the programme financially viable and freestanding. These incubator graduates have the potential to create jobs, revitalize neighborhoods, commercialize new technologies, and strengthen local and national economies.

United Kingdom Business Incubation (UKBI, 2007). Business Incubation is a unique and highly flexible combination of business development processes, infrastructure and people, designed to nurture and grow new and small businesses by supporting them through the early stages of development and change.

European Commission (EC, 2002). A business incubator is an organization that accelerates and systematises the process of creating successful enterprises by providing them with a comprehensive and integrated range of support, including: Incubator space, business support services, and clustering and networking opportunities.

By providing their clients with services on a 'one-stop-shop' basis and enabling overheads to be reduced by sharing costs, business incubators significantly improve the survival and growth prospects of new start-ups. A successful business incubator will generate a steady flow of new businesses with above average job and wealth creation potential. Differences in stakeholder objectives for incubators, admission and exit criteria, the knowledge intensity of projects, and the precise configuration of facilities and services, will distinguish one type of business incubator from another (p. 9). Organisation for Economic Co-operation and Development (OECD, 1997). Technology incubators are a specific type of business incubator: propertybased ventures which provide a range of services to entrepreneurs and startups, including physical infrastructure (office space, laboratories), management support (business planning, training, marketing), technical support (researchers, data bases), access to financing (venture capital funds, business angel networks), legal assistance (licensing, intellectual property) and networking (with other incubators and government services) (p. 4). Aernoudt (2004) An interactive development process where the aim is to encourage people to start their own business and to support start-up companies in the development of innovative products. (...) Besides accommodation, an incubator should offer services such as hands-on management, access to finance (mainly through links with seed capital funds or business angels), legal advice, operational know-how and access to new markets (p. 127)

Sherman and Chappell (1998). Business incubator is an economic development tool primarily designed to help create and new businesses in a community. Business incubators help emerging businesses by providing various support services, such as assistance in developing business and marketing plans, building management teams, obtaining capital, and access to a range of more specialized professional services. They also provide flexible space, shared equipment, and administrative services (p. 313). initiatives (Phan et al., 2005) providing their tenants with a mix of services encompassing infrastructure, business support services and networking (Bergek and Norrman, 2008; Hansen et al., 2000; Lalkaka and Bishop, 1996; Peters et al., 2004).

The goal and some impacts of BIs are also part of most definitions made by industry and large scale studies. The NBIA (2007) exemplifies this in claiming that graduating companies will be sustainable, and also help support technology commercialization and regional development. The EC study (2002) highlights the tenant firms' superior growth and their increased survival prospects. Researchers' definitions tend to focus more on their business support portfolio, specifying areas such as access to professional services (Sherman and Chappell, 1998) or capital (Aernoudt, 2004) as part of BIs' value proposition. Importantly, the NBIA definition emphasizes the role of the incubation manager and the relevance of providing services targeted at tenant companies' needs.

The concept of business incubation evolved since the establishment of the first BIs. Academic research has accompanied this evolution although most published studies are descriptive and use no consistent theoretical lens (Hackett and Dilts, 2004). We advance the working hypothesis of a generational sequence of BIs, and demonstrate that each generation of BIs added one dimension to their value proposition. Furthermore, we link each dimension to a different theoretical insight, namely economies of scale, learning, and networking theories.

\subsection{Evolution of business incubation: extending the value proposition}

\subsubsection{Infrastructure: economies of scale}

The first BIs were established in the USA in the 1950s (Adkins, 2002). The concept became widespread in the 1980s and spread to the rest of the world in a variety of forms (business centres, innovation centres, etc.) (EC, 2002). These first generation BIs offered affordable office space and shared resources (Barrow, 2001; Lalkaka and Bishop, 1996). Infrastructure is the basic function common to all kinds of BI and the core of their value proposition (Allen and McCluskey, 1990); it consists of office space rented in favourable conditions to incubatees (Bergek and Norrman, 2008). Furthermore, BIs often have small production facilities or mixed units available to tenants (OECD, 1997). Provision of space is critical to business incubation and has been identified by tenants as the most beneficial feature of BIs (Chan and Lau, 2005). Shared resources such as reception, clerical services, meeting rooms, conference rooms or car parking (EC, 2002; McAdam and McAdam, 2008) often complement office space and are normally available in BIs. More specialized resources, such as laboratories and research equipment, can also be regarded as part of an infrastructure proposition (Grimaldi and Grandi, 2005).

Tenants profit from existing economies of scale within BIs when renting office space together with shared resources. First, the existence of scale economies reduces tenants' overhead costs: each tenant enjoys office space together with a shared resources bundle including energy, water, telecommunications and cleaning. Second, BIs provide new firms with services they probably would not otherwise have access to during such early developmental stages, such as meeting rooms, reception services and private parking spaces. Third, this offer also eliminates the burden of planning, setting up and paying individual providers. Tenant companies do not have to put effort and time in managing complementary services, allowing them to concentrate on their core activities. Finally, the economies of scale are, in many cases, strengthened by BIs' subsidy generating capacity, which they partly share with their tenants. 


\subsubsection{Business support: accelerating the learning curve}

Governments in Europe and in the US were confronted during the 1980s with accelerating unemployment in mainstream sectors such as automobiles and heavy engineering (Reich, 1991). It became clear that innovation and technology were becoming the cornerstones of economic growth and that new strategies were necessary to revitalize economies. BIs became a popular tool to promote the creation of new technology-intensive companies (Lewis, 2001). Such companies need additional specific services beyond just affordable office space and shared resources. Nascent technology-intensive companies typically lack business experience and marketing skills and therefore may have limited chances for survival. BIs in this period reacted by including knowledge based services in their value proposition. As a result, this second generation of BIs already represented much more than just a physical arrangement for start-up companies (Smilor and Gill, 1986)

New firms often lack the necessary management skills and experience to cope with sudden environmental shifts and rapidly changing environments. Through a process of learning-by-doing, new firms change their behaviour and develop novel sets of routines. These routines include forms, rules, procedures, and strategies around which organizations are constructed and through which they operate (Levitt and March, 1988). People evaluate and make sense of the effects and organizational outcomes of past actions, and draw conclusions, which reshape their cognitive orientation (Bigley and Wiersema, 2002) and changing behaviour within the company. Developing routines and capabilities through experiential learning is a slow and gradual process (e.g. Dosi et al., 2000). The absence of such routines in firm's early stages contributes to a higher failure propensity (Freeman et al., 1983). At the same time, imperfect knowledge makes identifying and hiring relevant expertise very difficult. Moreover, founders may benefit from active coaching in addition to training (Clarysse and Bruneel, 2007; Kirwan et al., 2006). Consequently, incubated firms may avoid a process of trial and error and ascend more quickly the learning curve. As a result, these new ventures should be able to make better and faster decisions, resulting in better strategies and, eventually, higher firm performance (Eisenhardt, 1989b). Moreover, training sessions on relevant topics may contribute to increase ventures' knowledge bases and therefore positively impact on their development and performance (Colombo and Grilli, 2005; Davidsson and Honig, 2003).

Business support services such as coaching and training are crucial elements of learning within BIs. Coaching is typically mentioned as an important service that BIs provide to their tenants (Hansen et al., 2000; Mian, 1996). 'Coaching' refers to one-to-one support initiatives geared to accelerate tenants' learning and skill development processes, generally involving tenant firms being assigned coaches or mentors, either for a fee or free of charge (e.g. Barrow, 2001; Knopp, 2007). Such coaching typically covers both scientific and managerial areas of expertise (Clarysse and Bruneel, 2007). Coaching interactions between the incubated company and BI management increases tenants' understanding of buyer preferences (Scillitoe and Chakrabarti, 2010). Business support also is critical to tenants' timely graduation (Peters, et al., 2004), via its impact on firm development (cf. Robson and Bennett, 2000). Training is also often available within BIs (Aerts et al., 2007; Barrow, 2001) and has been found to positively influence tenants' performance (Peña, 2004).

\subsubsection{Networks: facilitating access to external resources, knowledge and legitimacy}

The third generation of BIs emerged during the 1990s with an emphasis on providing access to services via external networks
(EC, 2002; Lalkaka and Bishop, 1996). Network exploitation by BIs provides tenants with preferential access to potential customers, suppliers, technology partners and investors (Hansen et al., 2000; Scillitoe and Chakrabarti, 2010). Institutionalized networks established and managed by BIs ensure that networking is no longer dependent on individuals' personal networks or contacts (Bøllingtoft and Ulhøi, 2005). Hansen and colleagues posit that networking is the most important factor in successful BI programmes (2000), and empirical evidence suggests that access to networks is critical for BIs' tenant companies' development (McAdam and McAdam, 2008). In essence, facilitating access to external networks by BIs eases the acquisition of resources and specialized expertise, provides learning opportunities, and allows new firms to build up legitimacy faster.

In providing access to networks, BIs are contributing to helping new firms overcome their inherent resource scarcity. The lack of financial capital, experienced management teams, and capabilities hinders start-up companies' development and subsequent growth. Research shows that these firms can overcome their resource constraints through networking, and thereby accelerate firm growth (Zhao and Aram, 1995). Larson (1992) argues that entrepreneurial companies use networks to access resources beyond their financial capacity. BIs build networks with early stage investors such as business angel networks and venture capitalists, which reduce the search costs for tenants companies. Alongside providing necessary funds, venture capital investors can also play an important role in the professionalization of the venture (Gorman and Sahlman, 1989). Venture capitalists typically have a control function, supervising the firm's activities to safeguard their own investment, in tandem with supporting the growth of their portfolio companies. Consequently, venture capitalists contribute to the firm's development by meeting their financial needs as well as professionalizing organizational structure and managerial processes (Hellmann and Puri, 2002). Similarly, new firms can seldom access established networks for hiring specialized advice on highly specific topics such as technology development via linkages with academic institutions (Schwartz and Hornych, 2010), strategy consulting (Lee and Osteryoung, 2004) or patent attorneys (Rice, 2002). For instance, a venture seeking professional advice on a specific field of IP expertise might lack the financial means to pay high consultancy fees.

Partnering with other organizations also offers the opportunity to acquire new knowledge (Yli-Renko et al., 2001) and develop new capabilities (Lane and Lubatkin, 1998). Building knowledge and capabilities through inter-organizational relationships is faster than where the firm to internally develop the knowledge and capabilities (Bruneel et al., 2010). The acquisition of knowledge and real-time information is especially important in highvelocity markets where knowledge is advancing rapidly (Eisenhardt, 1989b). Networking with other companies also provides firms with greater legitimacy in the market place (Aldrich and Fiol, 1994) which in turn has a positive impact on their survival chances. Several studies have demonstrated that new firms have little organizational legitimacy, thereby limiting their opportunities for resource acquisition and reducing their survival propensity (e.g. Freeman et al., 1983; Hannan and Freeman, 1984). Singh et al. (1986) showed that the acquisition of legitimacy through exchange relationships with other organizations increases firms' survival chances. Table 2 summarizes the evolution of BIs and the theoretical rationale of each dimension.

\subsection{Selection criteria and exit policy of business incubators}

Alongside the service portfolio, business incubation also requires appropriate selection criteria and exit policies. These managerial features have been considered to be among one of BIs' 
Table 2

Summary of the evolution of business incubation's value proposition.

\begin{tabular}{|c|c|c|c|}
\hline & First generation & Second generation & Third generation \\
\hline Offering & Office space and shared resources & Coaching and training support & Access to technological, professional, and financial networks \\
\hline Theoretical rationale & Economies of scale & Accelerating the learning curve & Access to external resources, knowledge, and legitimacy \\
\hline
\end{tabular}

most important management features (Aerts et al., 2007; Lee and Osteryoung, 2004; Lumpkin and Ireland, 1988). If BIs select their tenants from a variety of sectors, for example, then providing tailored infrastructure, business support services and access to networks is more difficult than for a more homogeneous or sector-specific tenant population. Indeed, sector-specific BIs can achieve higher levels of economies of scale as their offerings are more specialized and tailored, with specialization increasing BIs' added value for tenant companies (Hansen et al., 2000; Schwartz and Hornych, 2008).

Firm age plays an important role in building organizations' capabilities and routines (Autio et al., 2000). In contrast to older organizations, young firms must actively shape their organizational structure, processes, and routines. Older organizations have developed substantive capabilities (Zahra et al., 2006) which hampers their ability to change their existing capability set and makes it more difficult to unlearn established routines. Organizations' needs also change as they grow, mature, and become more established (Clarysse and Bruneel, 2007) as do their typical problems encountered (Kazanjian, 1988). This is illustrated by the need for financing, which evolves in different stages, with those stages themselves changing in the different phases of the company lifecycle (Cieply, 2001). More generally, heterogeneity in terms of firms' age implies that BIs must implement different kinds of support mechanisms as firms' needs change as they develop (Vohora et al., 2004). But, as BIs' primary function is to support new venture creation (Aernoudt, 2004), there need be a recognition that services should focus firms' needs early in their life cycle, rather than helping relocating businesses.

BIs' exit policy should underpin an reasonable turnover of tenants, thereby also contributing to a more specialized service portfolio. An important characteristic of BIs is therefore timely tenant graduation (Rothaermel and Thursby, 2005a). BIs should enforce graduation within a 3 -year period, a relatively conservative time window (Rothaermel and Thursby, 2005a). BIs thus often incrementally increase rental rates to induce tenant graduation (Allen and McCluskey, 1990; Peters et al., 2004).

\section{Research design}

\subsection{Research context}

We utilize the multiple case study method to research the differences among generations of BIs. By doing so, we seek to advance the incubation literature by focusing on the "how" and "why" rather than the "what" questions (Hackett and Dilts, 2004). We therefore selected a small number of representative cases, following Eisenhardt and colleagues' recommendations (1989a; 2007). First, we wanted a representation of three generations of BIs. Hence, we selected BIs established in different time periods (1980s for the first generation, early 1990s for the second generation, and late 1990s-early 2000s for the third generation). Second, we selected BIs with a clearly stated mission of supporting new business creation. Whilst such a mission might seem a universal property of BIs, in reality some BIs seek to help existing companies to grow. We acknowledge that this research approach entails some shortcomings, especially with respect to generalizability and interpretative bias, and we therefore focused on a few best practices within each generation rather than the adoption of a general standard. Case study research is considered a powerful empirical research method to produce often unanticipated insights, and our case can be categorized as exploratory since our research question is to gain insights in the evolution of the value proposition of BIs (Yin, 2009).

The data for this paper was collected in two large projects exploring European BIs' best practices. In both projects, participating BIs were self-selected, denoting a willingness to improve incubation practices as well as to learn with peers. Also, researchers and practitioners worked collaboratively to ensure rigour of the topics explored as well as relevance of the results obtained (Schiele and Krummaker, 2011). Whilst this does not constitute a random sample, we contend that such cases provide a representative example of each BI generation. We note that previous studies have also used similar project-based data to overcome the difficulties of obtaining data on BIs and incubated companies (e.g. Carayannis and von Zedtwitz, 2005; Grimaldi and Grandi, 2005; Peña, 2004).

We study the Bedrijfs Technologisch Centrum Twente (NL) and Technologieförderung Münster (DE) as examples of first generation of BIs. The Bedrijfs Technologisch Centrum Twente (BTC) commenced operations in 1982. Located adjacent to the University of Twente campus in Enschede, the BI offers tenants about $4700 \mathrm{~m}^{2}$ of office space, workshops, and laboratories. The centre is profit oriented with its shareholders the University of Twente, Saxion University of Applied Sciences, ABN AMRO and Ten Hag, a regional real estate company. Its current mission is to house innovative high-tech companies with a preference for spin-out companies from the University of Twente. In recent years, BTC has been involved in several international projects sharing incubation best practices. Technologieförderung Münster (TFM) founded its first building in 1985 . Principally owned by the City of Münster (88\%), it provides its tenants with $6900 \mathrm{~m}^{2}$ of office space, workshops, laboratories and mixed use units. TFM is a non-profit regional development agency, promoting entrepreneurship courses in the region as well as managing regional networks in specific knowledge areas (e.g. Geonetzwerk Münsterland), often in partnership with local universities and research centres. In this study, we only consider companies located within the TFM's Technology Center.

The cases included in the second generation BIs are the Erasmus European Business \& Innovation Center (BE) and Jülich Technologiezentrum (DE). The Erasmus European Business \& Innovation Center (EEBIC) was created as a for-profit incubation centre in 1992 at the initiative of the Brussels-Capital Region and the Université Libre de Bruxelles. The $6000 \mathrm{~m}^{2}$ centre aims to stimulate and support high-tech entrepreneurs in the region. The incubation centre has a strong link with the Universite Libre de Bruxelles and plays an important role in university's research valorisation. Alongside an annual subsidy, EEBIC generates income from coaching services it provides to tenants, and office space rental. Jülich Technologiezentrum (JTZ) is part of a large network of German BIs (360 in total) and located in the Cologneregion. The centre was created to stimulate research commercialization of the nearby Research Centre through the creation of spin-off activity. With this purpose in mind, the regional government and the city of Jülich made an initial investment of 
15 million Euros. The centre did not receive further subsidies after founding nor does it take shares in the tenant companies, making office space rental JTZ's sole revenue source.

We selected Chalmers Innovation (Se), Normandie Incubation (Fr), and the Innovation Centre (UK) as cases to represent the third generation BIs. Chalmers Innovation $(\mathrm{CI})$ has been widely recognized and subsequently discussed in the literature as a best practice (e.g. Jacob et al., 2003). Chalmers Innovation's creation resulted from a five million Euro donation from "The Sten A. Olsson Foundation for Research and Culture" in 1997. This enabled the development in 1999 of a new $5000 \mathrm{~m}^{2}$ centre for "innovation related activities" - Chalmers Innovation -near to Chalmers University of Technology. Given the strong link with Chalmers University of Technology, the centre focuses on the incubation of technology-oriented start-ups. Cl's business model is based on three components: office space rental, subsidies and revenues from investing in the tenants. Normandie Incubation (NI) was established in 2000 as a direct result of the so-called French Law on Innovation and Research. This legislation sought to improve the valorisation of public research and made available in total 30 million Euros to set up BIs across France. NI brought together the Université de Caen Basse-Normandie, the École Nationale Supérieure d'Ingénieurs de Caen and the Grand Accélérateur National d'Ions Lourds as founders. Besides those three high education institutions, there are 14 further associate members (mainly regional public and private research institutes). NI selects nascent ventures based on their innovativeness and it allocates a maximum of 50,000 Euros for 24 months to support their establishment. NI is a small non-profit $\mathrm{BI}\left(300 \mathrm{~m}^{2}\right.$ for tenants) deriving its revenue primarily from national and regional public institutions, its members and European projects. Its tenants are required to pay rent with a two year lag and no interest. The Innovation Centre (IC) at DeMontfort University was founded in 2001 within its Leicester City Centre campus. The IC has 18 office units including two dedicated workshops for small production manufacturing and prototyping. The centre operates on a not-for-profit basis; revenues come primarily from the public sector $(75 \%)$ and tenants' rental payments $(25 \%)$. Table 3 provides an overview of the seven BIs' main characteristics.

\subsection{Data collection and methods}

We employed a two-step research design that spans a qualitative study of the selected BIs and a quantitative study of their tenants. First, we performed in-depth case studies of the supply side of incubation (BIs). The qualitative research methodology was preferred given the need for a deep understanding and local contextualization of the topic (Miles and Huberman, 1994). As suggested by Yin (2009), we undertook a comparative study to benchmark the different generation of BIs. The data for the first step was collected during semi-structured face-to-face interviews with key staff of BIs including as the manager and business developers; they are seen as expert advisors in their BIs. The number of key staff interviews ranged from three to six per BI, depending on the size of the BI's management team. Interviewing multiple informants per BI permitted triangulation of the data (Yin, 2009). These interviews had two goals: (a) to gain insight about the Bl's background, covering characteristics including shareholders, strategy, and brief history; and (b) to map the value proposition offered to tenants in terms of infrastructure, business support services, and access to networks. The use of semistructured interviews allowed interviewees to formulate their view on the BI through dialogue rather than simply answering a strict set of questions (Kvale, 2008). The semi-structured interview format serves as a guide to ensure all topics are covered. The length of the interviews was typically between 60 and $90 \mathrm{~min}$. The material was first read by all the different researchers involved, when points of interest were noted (Bryman, 2007). These different points of interest were then divided into several dimensions and combined with existing literature in order to identify differences and similarities between the cases (Easton, 1992). In this exercise, dimensions such as distinctive strategic objective (for-profit or not-for profit) (von Zedtwitz and Grimaldi, 2006), range of services offered (Chan and Lau, 2005), and sources of funding (Campbell and Allen, 1987) emerged, and the findings of this analysis are discussed further in Section 4.

In the second step of data collection, we interviewed a member of tenant companies' senior management - typically a founder or CEO - using a standardized questionnaire. Together with general company information (including age, size, and sector of activity), a key issue for these interviews was to gain insights into the extent to which tenants regarded the value proposition of their $\mathrm{BI}$ positively. The answers where then coded dichotomously corresponding to asking closed (yes/no) questions concerning usage of each available service. The data collection was carried out from early 2005 to late 2006. In total, we interviewed 71 tenants with a BI response rate ranging from 40\% (EEBIC) to $75 \%$ (NI). To ensure data triangulation (Yin, 2009), we duly collected additional data about the seven BIs and the 71 tenant companies via a range of secondary sources such as websites, organization brochures, annual reports, newsletters, and press releases. To reduce the potential of researcher bias, data collection at the BIs and tenants was shared among five researchers (all with prior interview experience). To increase data collection procedure uniformity across the different countries, the surveys were developed in English and all interviews were conducted in English.

\section{Supply side of business incubation}

This section focuses on the analysis of the supply side of business incubation by looking at BIs' value propositions. We

Table 3

General characteristics of the researched business incubators.

\begin{tabular}{|c|c|c|c|c|c|c|c|}
\hline & \multicolumn{2}{|c|}{ First generation } & \multicolumn{2}{|l|}{ Second generation } & \multicolumn{3}{|l|}{ Third generation } \\
\hline & BTC & TF Münster & EEBIC & Jülich TZ & $\begin{array}{l}\text { Chalmers } \\
\text { Innovation }\end{array}$ & $\begin{array}{l}\text { Normandie } \\
\text { Incubation }\end{array}$ & $\begin{array}{l}\text { Innovation Centre } \\
\text { @DMU }\end{array}$ \\
\hline Foundation date & 1982 & 1985 & 1992 & 1992 & 1998 & 2000 & 2001 \\
\hline Region & $\begin{array}{l}\text { Overijssel } \\
(\mathrm{Nl})\end{array}$ & $\begin{array}{l}\text { Münsterland } \\
\text { (De) }\end{array}$ & $\begin{array}{l}\text { Brussels-Capital Region } \\
\text { (Be) }\end{array}$ & $\begin{array}{l}\text { Cologne area } \\
\text { (De) }\end{array}$ & West Sweden (Se) & $\begin{array}{l}\text { Lower Normandy } \\
\text { (Fr) }\end{array}$ & East Midlands (UK) \\
\hline Business model & Profit & Not-for-profit & Profit & Not-for-profit & Profit & Not-for-profit & Not-for-profit \\
\hline Office space $\left(\mathrm{m}^{2}\right)$ & 4700 & 6900 & 6000 & 8000 & 5000 & 300 & 650 \\
\hline $\begin{array}{l}\text { Maximum number of } \\
\text { tenants }\end{array}$ & 68 & 42 & 23 & 36 & 18 & 18 & 18 \\
\hline
\end{tabular}


compare what BIs provide in terms of infrastructure, business support, and access to networks; we then discuss their selection criteria and exit policies. We group the analysis by BI generation.

\subsection{Value proposition}

\subsubsection{Infrastructure}

No significant differences regarding infrastructure across generations of BIs were found (Table 4). All provide turnkey office space, with the majority also offering small workshops and mixed premises for prototyping or small scale production. Reception, clerical services, parking and meeting rooms exist in every BI.

\subsubsection{Business support}

BIs of every generation provide coaching to their tenants companies (Table 4), although there are differences in the way they provide this kind of service. Erasmus European Business \& Innovation Center (EEBIC), Chalmers Innovation (CI) and Normandie Incubation (NI) stated they have in-house coaches: EEBIC and $\mathrm{CI}$ assembled a team of experts while within NI, the management team is the main source of coaching. Bedrijfs Technologisch Centrum Twente (BTC) and the Innovation Center (IC) provide tenants with outsourced coaches: BTC through one coach who is also an BI tenant while IC do this via a limited group of experts. Technologieförderung Münster (TFM) did not mention formal coaching either in-house or externally.

We considered training as consisting of formal organized workshops, seminars and access to complementary information. All generations of BIs provide this service to their tenants. While some frequently organize training sessions covering a range of small business and entrepreneurship topics (EEBIC and IC), others provide further training passively (BTC and TFM frequently distribute newsletters and announcements to their tenants) or grant access to workshops of some of their stakeholders (Jülich Technologiezentrum and $\mathrm{CI}$ ).

\subsubsection{Access to networks}

Professional business services are available for all generations of BIs. Access to these services may be provided passively by colocating with these services, including university technology transfer offices, consulting firms, insurance companies and project management firms (e.g. Jülich Technologiezentrum) within the Bl's premises. Conversely, Chalmers Innovation (CI) negotiated preferential agreements with major accounting, law and consulting firms to provide their tenants with a minimum level of pro bono advice hours. Normandie Incubation (NI) subsidizes its tenants to support access to professional services including scientific equipment and materials. The Innovation Center (IC) grants its tenant firms access to professional services through a regional network of BIs, the East Midlands Incubation Network (EMIN). This network provides the East Midlands' incubators with online training, workshops, seminars and frequent consultation with experts. Finally, first generation BIs - the Bedrijfs Technologisch Centrum Twente (BTC) and Technologieförderung Münster (TFM) - are similar in that provision of professional services is done by request and on demand.

Only the second and third generation BIs claimed to provide access to financial resources to their tenants. Jülich Technologiezentrum (JTZ) refers to one of their shareholders as the source for venture capital, whilst EEBIC established a business angel network, and $\mathrm{CI}$ a venture capital fund, as well as cooperating intensively with local venture capitalists. NI and the IC mentioned preferential access to finance resources within their networks.

\subsection{Selection criteria and exit policy}

BIs of all generations seldom mentioned a structured set of selection criteria. Yet, criteria such as technology focus, innovative products, high growth potential of the company were always preferred. BTC also demands solvency of the company whilst EEBIC places greater store by the analysis of the entrepreneurial team. TFM houses only biotechnology, nanotechnology and ICT companies. $\mathrm{NI}$ is the only $\mathrm{BI}$ having an comprehensive selection procedure: to be selected, prospective tenants must present a business plan to a committee composed of representatives of several shareholders. Additionally, NI occasionally provides business plan writing support. None of the BIs in any of the generations had clearly specified exit policies. EEBIC loosely mentioned time and performance criteria, with companies having to graduate after reaching a certain level of maturity, while BTC, TFM and JTZ stated no such criteria. The IC has the strictest criteria for exit: all tenants should leave after 36 months within the BI.

In summary, the three generations of BIs do not differ greatly in terms of what they offer to tenants. All generations provide their tenants with the same kind of infrastructure in terms of offices and shared resources. Furthermore, business support is also present in all generations of BIs, apart from TFM which did not mention any coaching/mentoring services. Access to resources is also similar across generations. The selection and exit policy are also similar across the three generations of BIs. Selection criteria are vague and poorly defined and a clear exit policy is often absent.

\section{Demand side of business incubation}

This section focuses on the demand side of incubation services, examining the extent to which tenant firms utilize the different dimensions of the value proposition. This is done by enquiring whether tenants make use of the offered infrastructure, business support services, and access to networks. We look more closely at the tenant profile in terms of their age, incubation period, size and entrepreneurial team characteristics. We group the tenant firms by BI generation which in turn allows us to perform statistical analysis in terms of group independence. The selected statistical test was the Kruskal-Wallis test. This one-way analysis of variance method allows us to test equality of population medians among groups. We also grouped the tenants by sector (biotechnology, micro-electronics, ICT, consulting, and other sectors) and repeated the analysis. The results of these additional KruskalWallis tests (using sector as a group variable) show that the usage of business incubation and the profile of the tenant companies are not statistically different between different industry sectors.

\subsection{Business incubation services}

Infrastructure was compared using the constructs 'space' and 'shared resources'. Space was described to tenants as available office or workshop space; shared resources was described as any complementary infrastructure-related shared service such as reception, car parking, meeting rooms and commodities. We did not find any statistically significant differences between the three generations regarding the usage of infrastructure (Table 5)

The situation is different when looking at the extent to which tenants use business support services, either coaching or training. We asked tenants about assigned coaches, either part of the BI team or provided through the BI. We found statistically significant differences for coaching $(p \leq .001)$. Almost all tenants in third generation BIs used coaching while older generation BIs' tenants tended not to use this service: half of the tenants in first generation BIs use coaching while less than a third of tenants in 


\begin{tabular}{|c|c|c|c|c|c|c|c|}
\hline & \multicolumn{2}{|l|}{ First generation } & \multicolumn{2}{|l|}{ Second generation } & \multicolumn{3}{|l|}{ Third generation } \\
\hline & BTC & TF Münster & EEBIC & Jülich TZ & Chalmers Innovation & Normandie Incubation & $\begin{array}{l}\text { Innovation Centre } \\
\text { @DMU }\end{array}$ \\
\hline $\begin{array}{l}\text { Infrastructure: } \\
\text { - Space } \\
\text { - Shared resources }\end{array}$ & $\begin{array}{l}\text { BTC provides } \\
\text { turnkeyturnkey office } \\
\text { space. Further shared } \\
\text { resources include } \\
\text { parking, reception and } \\
\text { meeting rooms. }\end{array}$ & $\begin{array}{l}\text { TFM provides } \\
\text { turnkeyturnkey office } \\
\text { space as well as } \\
\text { production facilities and } \\
\text { mixed units. Further } \\
\text { shared resources } \\
\text { include reception, } \\
\text { parking and meeting } \\
\text { rooms. }\end{array}$ & $\begin{array}{l}\text { EEBIC provides turnkey } \\
\text { office space as } \\
\text { production facilities, } \\
\text { laboratories and mixed } \\
\text { units. Shared resources } \\
\text { such as parking, } \\
\text { reception and meeting } \\
\text { rooms are also available. }\end{array}$ & $\begin{array}{l}\text { Jülich TZ IC provides } \\
\text { turnkey office space as } \\
\text { well as production } \\
\text { facilities and } \\
\text { laboratories. }\end{array}$ & $\begin{array}{l}\text { Chalmers provides } \\
\text { turnkey office space as } \\
\text { well as laboratories. } \\
\text { Shared resources such } \\
\text { as parking, reception and } \\
\text { meeting rooms are also } \\
\text { available. }\end{array}$ & $\begin{array}{l}\text { NI provides turnkey } \\
\text { office space to tenants } \\
\text { who only pay for it after } \\
\text { graduation and interest- } \\
\text { free. No further shared } \\
\text { resources are included. }\end{array}$ & $\begin{array}{l}\text { IC provides office } \\
\text { turnkey space as well } \\
\text { as small production } \\
\text { facilities ( } 2 \text { units). } \\
\text { Further shared } \\
\text { resources include } \\
\text { parking and reception. }\end{array}$ \\
\hline $\begin{array}{l}\text { Business support: } \\
\text { - Coaching } \\
\text { - Training }\end{array}$ & $\begin{array}{l}\text { Tenants access coaching } \\
\text { on an ad hoc basis via } \\
\text { incubator manager. One } \\
\text { tenant is a consultancy } \\
\text { firm who provides } \\
\text { coaching on a } \\
\text { commercial basis and } \\
\text { partially funded by } \\
\text { external sources. } \\
\text { Further training is } \\
\text { offered by the coaches } \\
\text { and consists of } \\
\text { newsletters.. }\end{array}$ & $\begin{array}{l}\text { No formal coaching team } \\
\text { exists. Training is offered } \\
\text { to tenants in the form of } \\
\text { information brochures, } \\
\text { emails newsletter or } \\
\text { punctual group sessions. }\end{array}$ & $\begin{array}{l}\text { Coaching team of three } \\
\text { in-house dedicated } \\
\text { experts. Their } \\
\text { backgrounds cover fields } \\
\text { such as accounting, } \\
\text { finance, marketing or } \\
\text { engineering. }\end{array}$ & $\begin{array}{l}\text { Coaching is provided by } \\
\text { a team of two coaches on } \\
\text { a part time basis. } \\
\text { Training session such as } \\
\text { seminars and workshops } \\
\text { are organized on } \\
\text { regularly basis in } \\
\text { collaboration with } \\
\text { Aachen Chamberof } \\
\text { Commerce. }\end{array}$ & $\begin{array}{l}\text { Own coaching team of } \\
\text { five multidisciplinary } \\
\text { experts: accounting, } \\
\text { finance, commercial and } \\
\text { business consulting } \\
\text { experience. }\end{array}$ & $\begin{array}{l}\text { Coaching team of two } \\
\text { dedicated project leaders } \\
\text { and a coach manager. } \\
\text { Their background is } \\
\text { mainly scientific. }\end{array}$ & $\begin{array}{l}\text { Coaching is provided } \\
\text { by outsourced coaches. } \\
\text { Their backgrounds } \\
\text { cover fields such as } \\
\text { management, } \\
\text { marketing or finance. }\end{array}$ \\
\hline $\begin{array}{l}\text { Access to Networks: } \\
\text { - Professional services } \\
\text { - Finance }\end{array}$ & $\begin{array}{l}\text { Access to professional } \\
\text { services is provided by } \\
\text { request and on demand } \\
\text { via incubator staff. } \\
\text { ABN is one of the } \\
\text { shareholders who may } \\
\text { provide financial } \\
\text { resources. }\end{array}$ & $\begin{array}{l}\text { Access to professional } \\
\text { services is provided by } \\
\text { request and on demand } \\
\text { via incubator staff. } \\
\text { A local savings bank } \\
\text { owns } 6 \% \text { of the incubator } \\
\text { who may provide } \\
\text { financial resources }\end{array}$ & $\begin{array}{l}\text { Professional services } \\
\text { such as patent attorneys, } \\
\text { legal counselling or } \\
\text { strategy consulting are } \\
\text { also available. EEBIC also } \\
\text { created its own business } \\
\text { angel network in } 1999 \\
\text { with as office within the } \\
\text { premises. }\end{array}$ & $\begin{array}{l}\text { Professional services: } \\
\text { one of the tenants is the } \\
\text { Technology Transfer } \\
\text { Office of that research } \\
\text { centre. Also, a legal } \\
\text { consulting firm, an } \\
\text { insurance company and a } \\
\text { project management } \\
\text { consulting firm are } \\
\text { located within the } \\
\text { premises. } \\
\text { One shareholder is a local } \\
\text { venture capital fund and } \\
\text { it is based within the } \\
\text { centre. }\end{array}$ & $\begin{array}{l}\text { Close collaboration with } \\
\text { Centre for Intellectual } \\
\text { Property. Other } \\
\text { professional services } \\
\text { include contractual } \\
\text { agreements with } \\
\text { accounting, law and } \\
\text { business consulting } \\
\text { firms. } \\
\\
\text { Chalmers manages its } \\
\text { own seed and venture } \\
\text { capital funds. Also, it } \\
\text { cooperates with local and } \\
\text { regional authorities, } \\
\text { private venture } \\
\text { capitalists and business } \\
\text { angels. } \\
\text { Chalmers also } \\
\text { collaborates intensively } \\
\text { with CONNECT. }\end{array}$ & $\begin{array}{l}\text { NI provides a subsidy } \\
\text { which can be used for } \\
\text { accessing professional } \\
\text { services (external advice } \\
\text { and expertise) as well as } \\
\text { scientific equipment and } \\
\text { materials. }\end{array}$ & $\begin{array}{l}\text { The IC is part of a } \\
\text { regional network to } \\
\text { exchange best practice } \\
\text { both for incubators and } \\
\text { incubatees which } \\
\text { includes a grand total } \\
\text { of } 16 \text { BIs. Through this } \\
\text { network, tenants can } \\
\text { access professional } \\
\text { services such as } \\
\text { training or online } \\
\text { support. Through this } \\
\text { network, tenants can } \\
\text { also access preferred } \\
\text { sources of finance. }\end{array}$ \\
\hline
\end{tabular}


Table 5

Usage of business incubation per generation of business incubator (\%).

\begin{tabular}{lllll}
\hline & $\begin{array}{l}\text { First } \\
\text { generation } \\
(N=25)\end{array}$ & $\begin{array}{l}\text { Second } \\
\text { generation } \\
(N=19)\end{array}$ & $\begin{array}{l}\text { Third } \\
\text { generation } \\
(N=27)\end{array}$ & -value \\
\hline $\begin{array}{l}\text { Infrastructure } \\
\begin{array}{l}\text { Space } \\
\text { Shared resources }\end{array}\end{array}$ & 100.0 & 100.0 & 100.0 & n.s. \\
$\begin{array}{l}\text { Business support } \\
\text { Coaching/ }\end{array}$ & 48.0 & 100.0 & 100.0 & n.s. \\
$\begin{array}{l}\text { Mentoring } \\
\text { Training to develop } \\
\text { business skills }\end{array}$ & 24.0 & 31.6 & 96.3 & $\leq .001$ \\
$\begin{array}{l}\text { Access to networks } \\
\begin{array}{l}\text { Professional } \\
\text { services providers }\end{array}\end{array}$ & 48.0 & 21.1 & 81.5 & $\leq .001$ \\
$\begin{array}{l}\text { Seed or venture } \\
\text { capital }\end{array}$ & 12.0 & 63.2 & 96.3 & $\leq .001$ \\
\hline
\end{tabular}

second generation BIs use such services. The results also show statistical difference between the three generations of BIs for the usage of training services by tenants $(p \leq .001)$; less than a quarter of both first and second generation BIs' tenants make use of this kind of service. Conversely, the overwhelming majority of third generation BIs' tenants make use of training services.

The access to networks shows the same pattern as the dimensions previously discussed. We enquired concerning tenants' usage of professional business services and access to finance. Professional business services are specialized support services the BI provides in a formalized manner through their network of contacts. These include accounting, legal or administrative support, as well as more specialized services such as strategy consulting or patent attorneys. Data suggests that it was principally the third generation BIs' tenants that made use of professional service providers. Only about half of both the second and third generation BIs' tenants used this kind of service. The differences are statistically significant $(p \leq .001)$. The same is true for seed or venture capital $(p \leq .001)$. Whilst more than twothirds of third generation BIs' tenants were able to access financial means through their BI, only about half of their second generation counterparts stated the same, and. first generation BIs' tenants barely mentioned this.

These results show that tenants value their BI's value proposition differently. More third generation BIs' tenants make use of the entire service portfolio (including infrastructure, business support services, and access to networks) than their counterparts housed in older generation BIs. In terms of business support, first generation BIs' tenants enjoy more coaching and training than their second generation counterparts (Table 5).

\subsection{Selection criteria and exit policy: profile of tenant companies}

We researched the selection criteria and exit policy by looking at the tenant profile. Tenants' characteristics (including age at entry, share of serial entrepreneurs, and share of relocated companies) can be translated into the selection criteria. We start by looking individually at each of the variables we considered reflective of the selection criteria. Table 5 shows that there is a significant difference between the tenants firms regarding their age at entry $(p \leq .05)$. Third generation BIs' tenants are very young (less than one year old) at the moment they enter the BI. First generation BIs' tenants are almost two years old while the firms located in second generation BIs are more than seven years old.

To complement the tenants' profile, we also examine whether there are differences among the firms' entrepreneurial teams,
Table 6

Profile of tenants per generation of business incubator.

\begin{tabular}{|c|c|c|c|c|}
\hline & $\begin{array}{l}\text { First } \\
\text { generation } \\
(N=25)\end{array}$ & $\begin{array}{l}\text { Second } \\
\text { generation } \\
(N=19)\end{array}$ & $\begin{array}{l}\text { Third } \\
\text { generation } \\
(N=27)\end{array}$ & $p$-value \\
\hline Entry age & 1.76 & 7.1 & .85 & $\leq .05$ \\
\hline $\begin{array}{l}\text { Relocated } \\
\text { tenants (\%) }\end{array}$ & 44.0 & 52.6 & 22.2 & $\leq .10$ \\
\hline $\begin{array}{l}\text { Years in } \\
\text { incubator }\end{array}$ & 5.12 & 5.00 & 1.70 & $\leq .001$ \\
\hline Firm size & 3.68 & 8.21 & 2.33 & $\leq .01$ \\
\hline $\begin{array}{l}\text { Serial } \\
\text { entrepreneurs } \\
(\%)\end{array}$ & 25.0 & 36.8 & 53.8 & $\leq .10$ \\
\hline
\end{tabular}

through the extent to which they have previous experience in starting businesses. Table 6 shows that the majority of third generation tenant firms are established by entrepreneurs who have previously founded a company. Conversely, less than half of the second generation, and only a quarter of the first generation firms, have serial entrepreneurs in their team. Summarizing, we find that the tenants' profile differ significantly between the generations of BIs. Finally, we looked at the percentage of relocated firms in the BIs at the moment of data collection. We considered relocated firms as companies created one year or more prior to entering the BI. Almost half of the first generation BI tenants, and more than 50 per cent of the second generation $\mathrm{BI}$ tenants were founded one year or more before entering the BI (Table 6). Conversely, only about a fifth of the third generation BIs' companies were neither created at the Bl's premises nor moved there in their first year of existence.

We now turn our attention to the exit policies by looking at the length of the firm's incubation period, i.e. the number of years elapsed since each tenant's entry to the BIs, and the firm's size. Third generation BIs' tenants stay less than two years in their respective BIs whereas their first and second generation counterparts stay for much longer periods $(p \leq .001)$ (Table 6). Since the tenants of the first and second generation BIs are significantly older when entering the BI and show longer incubation periods, it is unsurprising to see that the first and second generation BIs tenants are significantly larger in terms of employees $(p \leq .01)$.

In summary, we see a significant difference in the usage of business incubation and profile of the tenant companies between the different BI generations. First and second generation BIs' tenants are older when entering the BI and typically stay longer in incubation than first generation BIs' tenants. This implies that tenant companies in the first and second generation have built greater stocks of knowledge, and developed more capabilities and routines than have their younger counterparts in the third generation BIs.

\section{Discussion and implications}

Our study conceptualizes BIs in a new theoretical framework representing the evolution of their value proposition. This effort responds directly to a recent call made by Hackett and Dilts (2004) to develop a more theoretically grounded approach to incubation. We embed the value proposition of BI in theories of economies of scale, learning, and networking. Economies of scale refer to the most basic service of BIs: offering infrastructure and shared services. BIs also provide coaching and training support through its management team. Finally, BIs have a boundary-spanning function in facilitating access to different types of resource and service providers through institutionalized networks. 
We confirmed our working hypothesis of the existence of generations of BIs showing that, indeed, there are differences in the way service portfolios are used by tenants located in BIs founded in different points in time. Yet, when looking exclusively at the BIs, we found similar service portfolios. This means that, over time, first generation BIs extended their value proposition by adding business support services (characterizing the second generation) and access to networks (characterizing the third generation) to their offer. We also observed this phenomenon for the second generation BIs, who had added networking to their value proposition. As a result, today's BI landscape appears very homogeneous in terms of the value proposition. This could potentially be a result of industry attempts to standardize BIs through professional associations (e.g. NBIA, UKBI) and the pressure to comply with every stakeholder's expectations.

The confirmation of the existence of BIs generations identified by service provision levels advances in our understanding of BIs. Despite the typologies found in previous work (e.g Carayannis and von Zedtwitz, 2005; von Zedtwitz and Grimaldi, 2006), our generation argument introduces a tenant-centred view of BIs. Categories typically relate BI ownership to service profiles (von Zedtwitz and Grimaldi, 2006) or goals to managerial practices (Clarysse et al., 2005). Our results show that even if those typologies are true, older BIs tend to not achieve major changes in their offer and therefore their complete value proposition is relevant only to a low share of their tenant companies. These findings also differ fundamentally from Allen's (1988) argument. Allen (1988) suggested that each BI evolves from an initial focus in infrastructure to business support and only later providing access to networks to incubated companies. Our evidence suggests that other forces may keep BIs in their first stage of development (i.e. focused on infrastructure).

BIs operate in a politically charged environment where they must demonstrate the success of their activities in order to justify public support (Hackett and Dilts, 2004). The subsidy-dependence of BIs enforces compliance with industry and government views on how they should operate. As a result, BIs "need to look good in the eyes of policy actors in order to gain increased income" (Aaboen, 2009, p. 667). Aaboen argues that BIs must satisfy both the tenants and policy actors equally as their most important customers. Our study shows that first and second generation focus efforts on satisfying policy actors by expanding their portfolio beyond mere infrastructure and intangible services. They appear to be less concerned with assessing the alignment of their service portfolio to their tenant profile. In contrast, third generation BIs succeed in serving policy actors' as well as tenants' goals.

Third generation BIs' tenants are younger, smaller and have shorter incubation periods than tenants housed in first and second generation BIs. These findings suggest that third generation BIs differ in terms of their tenant target group from first and second generation BIs. Third generation BIs are more focused on starting up companies, shown by the higher number of companies established within the $\mathrm{BI}$; first and second generation BIs have a significantly higher number of relocated companies. Also, these tenants graduate within less than three years on average suggesting that third generation BIs are acting as engines for new venture creation. In contrast, the turnover of tenants in the first and second generation BIs is significantly lower. Data suggests that both generations house tenants less likely to use the full range of services available, but for different reasons. Tenants located in first generation BIs enter at a young age, remain relatively small and show little growth ambition: only around $10 \%$ seek access to external financing such as business angels or venture capital. Conversely, second generation BI tenants enter at a mature age, have long duration tenancies and are larger. They also tend to be more actively looking to attract external financing which signals greater growth ambition. These phenomena can be seen as the revealed mission of each BI generation. Our study therefore answers the question of why so many older generation BIs fail to provide their promised incubation and support services (Hansen et al., 2000).

First and second BI generations provide fewer tenants with services. This means that these older generation BIs are intervening less often and in fewer companies that their third generation counterparts. To some extent, first and second generation BIs seem to function as science parks (SP) and are therefore complementary to those of the third generation. (We gratefully thank an anonymous reviewer for raising this point.) BIs and SPs are two distinct types of initiatives fulfilling different roles in the value chain of support activities. BIs typically facilitate the creation of new ventures as well support them throughout their initial stages of development. SPs aggregate companies while also providing some business support services and therefore can be useful for graduated incubated companies, making BIs potentially tenant-feeders to science parks (Ratinho and Henriques, 2010). Our findings suggest that tenants located in first and second generation BIs might be much more similar to those located on SPs rather than those in third generation BIs. We extend previous work that links differences in usage of incubation services according to the venture's lifecycle stage (e.g. McAdam and McAdam, 2008), providing evidence that not only each service becomes less important but it also might be rendered superfluous.

The potential value creation of each BI generation is quite different to their stated mission. All BIs in our sample claim to be in the vanguard of new firm creation as well as having enhancing their tenants' long term survival and performance. Yet only third generation BIs seem able to contribute actively to new company creation. First and second generation BIs reveal the practice of housing established companies. First generation BIs select young companies, allowing them a long stay without promoting or encouraging their growth. Second generation BIs recruit more mature companies seeking perhaps to guarantee more stable revenue. Both generations of BIs show a greater concern in renting out property rather than creating new companies, particularly the second generation since they allow relatively large companies as tenants. Finally, third generation BIs show a great focus in selecting nascent companies and graduating them quickly, keeping a reasonable turnover in the BI and supporting a larger number of companies. This finding is in line with Kuratko and LaFollette (1987) who found that BIs' selection criteria and exit policy should be aligned with their objectives. If not, BIs are unable to fulfil their role in nurturing and supporting new ventures. Previous work has already assessed different strategies to incubate new ventures (e.g. Clarysse et al., 2005). Our data is complementary in revealing BIs' activities by looking at their tenants rather than at their missions and public activities.

\subsection{Implications for BI managers, prospective tenants and policy makers}

Our results yield several important implications for BI managers, prospective tenants and policy makers. First, third generation BIs are unlikely to be profitable because they select nascent ventures. Although their tenants are often serial entrepreneurs and therefore more experienced in starting business, they have less-well developed business processes and are possibly more aware of their shortcomings. As a result, their tenants are more likely to use the complete service portfolio whilst in the process of establishing their companies. Being nascent ventures, these tenants do not generate enough revenue to cover BIs' operational costs for offering business support services and access to 
networks. Therefore, this generation of BI requires significant and long-term public funding to be sustainable, or other alternatives such as taking stakes in, or a percentage of future turnover of, their tenants. Conversely, first and second BIs may aim for a selfsustainable model with limited government funding. The limited usage of business support services suggests that first and second generation BIs' tenants are already experienced, having developed a capability base and a set of business routines. In other words, these companies are relatively more mature and therefore more likely to have established a stable revenue base.

Second, if no adequate tenant turnover is promoted and supported by clear selection criteria and exit policies, tenants will develop skills and capabilities through experience, and no longer require business support services. This has been even more pronounced where first generation BI have added access to networks to their service portfolios. Our results show that first and second generation BIs select older tenants that stay longer in the BI, thus needing less business support services and access to networks than newly founded ventures.

Third, progressing from providing infrastructure to coaching and networking turns out to be a very difficult step for BIs and involves much more than establishing an extended service portfolio. First and second generation BIs extended their value proposition while not adjusting their selection criteria and exit policy (most BIs in our sample do not have clear selection criteria and exit policies in place). We found that first and second generation BIs are selecting more mature companies and, in case of second generation $\mathrm{BI}$, even permitting tenancies beyond the typical incubation period of three years (EC, 2002). The length of the incubation period is also much higher in first and second generation BIs. As a result, a mismatch emerges between the tenant profile and the services offered and, ultimately, renders those services inadequate. Therefore, BI managers should be more aware of the impact of updating their value proposition. Adding dimensions such as business support and access to networks only makes sense if combined with adequate BI management practices. Appropriate selection and exit procedures guarantee the admission of tenants who are more likely to use services such as business support or networking and ensure that tenants graduate in timely a way. As the value proposition for the three generations is similar, all generations of BIs should accommodate new ventures as they are most likely to use all three components: infrastructure, business support, and access to networks.

Fourth, prospective tenants should look at their future fellow tenants to better assess and select an appropriate BI in addition to assessing the BI's profile (Schwartz and Hornych, 2008). While this may sound counter-intuitive, it better informs prospective tenants than checking the BIs' offering. As shown, BIs across generations tend to standardize their value proposition and state a similar mission. Yet our analysis of tenants' population and the extent to which they use business support and access to external networks uncovers a different picture; if the prospective tenant is looking for a dynamic, vibrant environment then it should look for a third generation BI. Here, the prospective tenant will encounter fellow tenants that are confronted with similar challenges thereby offering more opportunities for mutual learning and exchange of experiences.

Fifth, policy makers should be more aware of the extent to which different generations of BIs affect their tenants. If the ambition of policy is to stimulate and support new venture creation then planning to upgrade older generations of BIs is counterproductive if not accompanied by a simultaneous shift in management practices. More specifically, policy makers should enforce an adjustment of selection criteria and exit policies by BI managers, ensuring support tailored to nascent companies and a healthy turnover of tenants. However, our findings reveal that BIs do not always implement their stated selection criteria and exit policies. This calls for further monitoring of BIs' operations and practices to ensure their contribution to policy objectives. A possible reason for not changing these procedures might be found in BIs' financial goals. Renting property is an important base for the sustainability of BIs, they cannot change their tenant composition from stable tenants to (the more insecure group of) nascent entrepreneurs without any financial compensation. Another reason may be the marketing role of BIs to policy makers. BIs often function symbolically for policy makers to demonstrate their commitment towards innovation and entrepreneurship (Schwartz and Hornych, 2008). Policy makers may therefore be tempted to provide further funding to older generation BIs to update their service portfolio to current standards.

Therefore, policy makers should make more careful assessments of BIs before allocating funding to support these institutions. From a policy perspective, it is therefore important to study the tenant profile as this highlights the extent to which BIs do or do not require public funding. Our study reveals that first and second generation BIs house tenants that are more mature and generate more stable revenue streams. These findings are in line with Mønsted's (2000) who suggests that science parks are also more likely to fill up units with any rent-paying activity rather than exclusively supporting novel entrepreneurship. Although their initial mission was to generate high technology growth, limited subsidized office space for innovative start-ups forced science parks to turn to mature companies as tenants able to afford the high rental fees. First and second generation BIs appear to similarly select tenants able to generate sufficient rental income allowing the BI to cover its operational expenses. In contrast, third generation BIs select nascent ventures that typically do not have fully developed business models, very limited or no revenues and thus involve a much higher risk. These BIs will be forced to provide office space for free or at a fee significantly below market prices. In addition, tenants in third generation BIs are likely to use the service portfolio more extensively as they regard it as being valuable. As a result, the first and second generation of BIs may require less public funding compared to their first generation counterparts.

\subsection{Limitations and further research}

This study is not without limitations, which provide avenues for future research. Our paper is based on a detailed analysis of seven BIs in North Western Europe and 71 of their tenant companies. Future research should use larger-scale studies in other geographical regions including more BIs per generation to provide further validation of our findings. A longitudinal examination of BIs' service portfolio and longitudinal usage of these services by tenants would also bring more insights into the dynamics of business incubation.

Further developing our theoretical framework should be the basis for future research. Our analysis suggests that anchoring BIs in three dimensions is useful. Yet when discussing the results, BIs' long-term strategic goals emerged as possible explanations for our findings. As a result, our framework would be greatly improved by adding BIs' features beyond service provision, and further research may wish to consider the role of the BIs' business model in the extent to which value proposition and tenant profile are aligned. For example, it may be that the business model of first and second generation BIs is more dependent on rental income because they receive less subsidies than their third generation counterparts. Similarly to science parks (Mønsted, 2000), the former BIs may need to house mature firms that can pay the high rental fees thereby avoiding bankruptcy. 
Whilst beyond the scope of this paper, an interesting avenue for future research is to study the impact of location at different generations of BI upon tenant performance. The three identified generations of BIs house tenants with very different characteristics. Tenants of third generation BIs are new firms created by serial entrepreneurs whereas first and second generation BIs' tenants are typically older when they enter the BI, having been founded by novice entrepreneurs. By taking into account these differences between the three generations of BIs, future studies may reconcile some of the contradictions in studies on the performance implications of business incubation.

From a methodological point of view, we focused on BIs that offered physical office space and therefore excluded virtual BIs (Durão et al., 2005; Nowak and Grantham, 2000). This type of business BI focuses efforts on providing business expertise and facilitating access to strategic partnerships (Nowak and Grantham, 2000). It does not, however, offer the key function of the first generation: economies of scale through shared infrastructure and basic services. Future research that also considers this very recent type of business BI would clearly complement our findings.

A final addition to our study would be to collect additional data for each service in at least two ways: the method/quality of provision and the intensity/frequency of provision. For example, although every BI claims to provide coaching to its tenants, significant differences exist in the way coaching is provided and between the background/experience of the coaches. Additionally, the time dedicated to each service potentially differs across BIs. Future research should take this into account and thereby complement this study's insights.

\section{Conclusions}

We set out to research whether older generation BIs updated their service portfolio to cover today's incubation paradigm, and the extent to which the service portfolio fits each generation of $\mathrm{BI}$ tenants. Based on seven case studies representing the three generations of BIs, we observe no significant differences across generations in terms of their service portfolio. However, using survey data of 71 tenants collected within the same seven BIs, we find that only firms located in third generation BIs make full use of the service portfolio. Furthermore, older generation BIs select older tenants and allow them to stay longer. This suggests that it is this lack of selection criteria and exit policies within the BI that are at the root of the mismatch between supply and demand for business incubation. Our findings also indicate that BIs might experience a kind of imprinting effect: older generation BIs are not capable of fully adapting to the newer models of incubation not so much because of difficulties in establishing new services, but due to rigidities in their management practices. We hope that our study encourages researchers in the field of business incubation to take our approach as a departure point for large-scale longitudinal studies.

\section{References}

Aaboen, L., 2009. Explaining incubators using firm analogy. Technovation 29 (10), 657-670.

Adkins, D., 2002. A Brief History of Business Incubation in the United States. National Business Incubation Association, Athens, Ohio.

Aernoudt, R., 2004. Incubators: tool for Entrepreneurship? Small Business Economics 23 (2), 127-135.

Aerts, K., Matthyssens, P., Vandenbempt, K., 2007. Critical role and screening practices of European business incubators. Technovation 27 (5), 254-267.

Aldrich, H.E., Fiol, C.M., 1994. Fools rush in? The institutional context of industry creation. The Academy of Management Review 19 (4), 645-670.
Allen, D.N., 1988. Business incubator life cycles. Economic Development Quarterly 2 (1), 19-29.

Allen, D.N., McCluskey, R., 1990. Structure, policy, services, and performance in the business incubator industry. Entrepreneurship: Theory \& Practice 15 (2), 61-77.

Autio, E., Sapienza, H.J., Almeida, J.G., 2000. Effects of age at entry, knowledge intensity, and imitability on international growth. The Academy of Management Journal 43 (5), 909-924.

Barrow, C., 2001. Incubator: A Realist's Guide to the World's New Business Accelerators. John Wiley \& Sons Ltd., West Sussex, UK.

Bergek, A., Norrman, C., 2008. Incubator best practice: a framework. Technovation $28(1-2), 20-28$

Bigley, G.A., Wiersema, M.F., 2002. New CEOs and corporate strategic refocusing: how experience as heir apparent influences the use of power. Administrative Science Quarterly 47 (4), 707-727.

Bøllingtoft, A., Ulhøi, J.P., 2005. The networked business incubator-leveraging entrepreneurial agency? Journal of Business Venturing 20 (2), 265-290.

Bruneel, J., Yli-Renco, H., Clarysse, B., 2010. Learning from experience and learning from others: how congenital and interorganizational learning substitute for experiential learning in young firm internationalization. Strategic Entrepreneurship Journal 4 (2), 164-182. doi:10.1002/sej.89.

Bryman, A., 2007. Qualitative data analysis. SAGE Pulications, London, UK.

Campbell, C., Allen, D.N., 1987. The small business incubator industry: micro-level economic development. Economic Development Quarterly 1 (2), 178-191.

Carayannis, E.G., von Zedtwitz, M., 2005. Architecting gloCal (global-local), realvirtual incubator networks (G-RVINs) as catalysts and accelerators of entrepreneurship in transitioning and developing economies: lessons learned and best practices from current development and business incubation practices. Technovation 25 (2), 95-110.

Chan, K.F., Lau, T., 2005. Assessing technology incubator programs in the science park: the good, the bad and the ugly. Technovation 25 (10), 1215-1228.

Cieply, S., 2001. Bridging capital gaps to promote innovation in France. Industry and Innovation $8(2), 159-178$

Clarysse, B., Bruneel, J., 2007. Nurturing and growing innovative start-ups: the role of policy as integrator. R\&D Management 37 (2), 139-149.

Clarysse, B., Wright, M., Lockett, A., Van de Velde, E., Vohora, A., 2005. Spinning out new ventures: a typology of incubation strategies from European research institutions. Journal of Business Venturing 20 (2), 183-216.

Colombo, M.G., Delmastro, M., 2002. How effective are technology incubators? evidence from Italy. Research Policy 31 (7), 1103-1122.

Colombo, M.G., Grilli, L., 2005. Founders' human capital and the growth of new technology-based firms: a competence-based view. Research Policy 34 (6) $795-816$

Davidsson, P., Honig, B., 2003. The role of social and human capital among nascent entrepreneurs. Journal of Business Venturing 18 (3), 301-331.

Dosi, G., Nelson, R.R., Winter, S.G., 2000. The Nature and Dynamics of Organizational Capabilities. In: Dosi, G., Nelson, R., Winter, S. (Eds.), The Nature and Dynamics of Organizational Capabilities. , Oxford University Press, New York, NY.

Durão, D., Sarmento, M., Varela, V., Maltez, L., 2005. Virtual and real-estate science and technology parks: a case study of Taguspark. Technovation 25 (3) 237-244.

Easton, G., 1992. Learning from Case Studies, 2nd ed. Prentice Hall, Harlow, UK.

EC, 2002. Benchmarking of Business Incubators, Final Report. Brussels.

Eisenhardt, K.M., 1989a. Building theories from case study research. The Academy of Management Review 14 (4), 532-550.

Eisenhardt, K.M., 1989b. Making fast strategic decisions in high-velocity environments. The Academy of Management Journal 32 (3), 543-576.

Eisenhardt, K.M., Graebner, M.E., 2007. Theory building from cases: opportunities and challenges. Academy of Management Journal 50 (1), 25-32.

Freeman, J., Carroll, G.R., Hannan, M.T., 1983. The liability of newness: age dependence in organizational death rates. American Sociological Review 48 (5), 692-710

Gorman, M., Sahlman, W.A., 1989. What do venture capitalists do? Journal of Business Venturing 4 (4), 231-248.

Grimaldi, R., Grandi, A., 2005. Business incubators and new venture creation: an assessment of incubating models. Technovation 25 (2), 111-121.

Hackett, S., Dilts, D., 2004. A systematic review of business incubation research The Journal of Technology Transfer 29 (1), 55-82.

Hannan, M.T., Freeman, J., 1984. Structural inertia and organizational change American Sociological Review 49 (2), 149-164.

Hansen, M.T., Chesbrough, H.W., Nohria, N., Sull, D.N., 2000. Networked incubators. Harvard Business Review 78 (5), 74-84.

Hellmann, T., Puri, M., 2002. Venture capital and the professionalization of startup firms: empirical evidence. The Journal of Finance 57 (1), 169-197.

Jacob, M., Lundqvist, M., Hellsmark, H., 2003. Entrepreneurial transformations in the Swedish University system: the case of Chalmers University of Technology. Research Policy 32 (9), 1555-1568.

Kazanjian, R.K., 1988. Relation of dominant problems to stages of growth in technology-based new ventures. The Academy of Management Journal 31 (2) 257-279.

Kirwan, P., van der Sijde, P., Groen, A., 2006. Assessing the needs of new technology based firms (NTBFs): an investigation among spin-off companies from six European Universities. The International Entrepreneurship and Management Journal 2 (2), 173-187. 
Knopp, L., 2007. State of the Business Incubation Industry. National Business Incubation Association, Athens, Ohio 2006.

Kuratko, D.F., LaFollette, W.R., 1987. Small business incubators for local economic development. Economic Development Review 5 (2), 49-55.

Kvale, S., 2008. Doing Interviews. Sage Publications, London, UK.

Lalkaka, R., Bishop, J., 1996. Business Incubators in Economic Development-an Initial Assessment in Industrialising Countries. United Nation Development Programme, New York.

Lane, P.J., Lubatkin, M., 1998. Relative absorptive capacity and interorganizational learning. Strategic Management Journal 19 (5), 461-477.

Larson, A., 1992. Network Dyads in entrepreneurial settings: a study of the governance of exchange relationships. Administrative Science Quarterly 37 (1), 76-104.

Lee, S.S., Osteryoung, J.S., 2004. A comparison of critical success factors for effective operations of university business incubators in the United States and Korea. Journal of Small Business Management 42 (4), 418-426.

Levitt, B., March, J.G., 1988. Organizational learning. Annual Review of Sociology $14,319-340$

Lewis, D.A., 2001. Does technology incubation work? A critical review. Retrieved from 〈http://www.eda.gov/ImageCache/EDAPublic/documents/pdfdocs/ lewis_5frutgers_5frept_2epdf/v1/lewis_5frutgers_5frept.pdf $\rangle$.

Lewis, D.A., 2010, (March 17th, 2010). Business Incubators and Their Role in Job Creation. U.S. House of Representatives Committee on Small Businesses. Retrieved October 25th, 2010, from 〈http://www.house.gov/smbiz/hearings/ hearing-3-17-10-business-incubators/Lewis.pdf $\rangle$.

Lumpkin, J.R., Ireland, R.D., 1988. Screening practices of new business incubators: the evaluation of critical success factors. American Journal of Small Business 12 (4), 59-81.

Massey, D., Quintas, P., Wield, D., 1992. High-Tech Fantasies: Science Parks in Society, Science and Space. Routhledge, London.

McAdam, M., McAdam, R., 2008. High tech start-ups in University Science Park incubators: the relationship between the start-up's lifecycle progression and use of the incubator's resources. Technovation 28 (5), 277-290.

Mian, S.A., 1996. Assessing value-added contributions of university technology business incubators to tenant firms. Research Policy 25 (3), 325-335.

Miles, M.B., Huberman, A.M., 1994. Qualitative Data Analysis: An Expanded Sourcebook, 2nd ed. Sage, Thousand Oaks, CA

Mønsted, M., 2000. Strategic Networking in Science Parks: The Bazaar-Principle for Organising High Technology. In: During, W., Oakey, R., Kipling, M. (Eds.), New Technology-Based Firms at the Turn of the Century. , Pergamon, Oxford, UK, pp. 192-202.

NBIA, 2007. Business incubation FAQ. Retrieved 28.05.2008, from 〈http://www. nbia.org/resource_center/bus_inc_facts/index.php $>$.

NBIA, 2011. Business incubation FAQ. Retrieved 24.01.2011, from <http://www. nbia.org/resource_library/faq/index.php\#6 $>$.

Nowak, M.J., Grantham, C.E., 2000. The virtual incubator: managing human capital in the software industry. Research Policy 29 (2), 125-134.

OECD, 1997. Technology Incubators: Nurturing Small Firms. Organisation for Economic Co-Operation and Development, Paris.

OECD, 1999. Business Incubation: International Case Studies. Organisation for Economic Co-Operation and Development, Paris.

OECD, 2010. High-Growth Enterprises-What Governments Can Do to Make Difference. OECD Publishing, Paris.

Peña, I., 2004. Business incubation centers and new firm growth in the basque country. Small Business Economics 22 (3), 223-236.
Peters, L., Rice, M., Sundararajan, M., 2004. The role of incubators in the entrepreneurial process. The Journal of Technology Transfer 29 (1), 83-91.

Phan, P.H., Siegel, D.S., Wright, M., 2005. Science parks and incubators: observations, synthesis and future research. Journal of Business Venturing 20 (2), 165-182.

Ratinho, T., Henriques, E., 2010. The role of science parks and business incubators in converging countries: evidence from Portugal. Technovation 30 (4), 278-290.

Reich, R., 1991. The Work of Nations. Simon \& Schuster, London.

Rice, M.P., 2002. Co-production of business assistance in business incubators: an exploratory study. Journal of Business Venturing 17 (2), 163-187.

Robson, P., Bennett, R., 2000. SME Growth: the relationship with business advice and external collaboration. Small Business Economics 15 (3), 193-208.

Rothaermel, F.T., Thursby, M., 2005a. Incubator firm failure or graduation?: The role of university linkages. Research Policy 34 (7), 1076-1090.

Rothaermel, F.T., Thursby, M., 2005b. University-incubator firm knowledge flows: assessing their impact on incubator firm performance. Research Policy 34 (3), 305-320.

Schiele, H., Krummaker, S., 2011. Consortium benchmarking: collaborative academic-practitioner case study research. Journal of Business Research 64 (10), 1137-1145.

Schwartz, M., Hornych, C., 2008. Specialization as strategy for business incubators: an assessment of the Central German Multimedia Center. Technovation 28 (7), 436-449.

Schwartz, M., Hornych, C., 2010. Cooperation patterns of incubator firms and the impact of incubator specialization: empirical evidence from Germany. Technovation 30 (9-10), 485-495.

Scillitoe, J.L., Chakrabarti, A.K., 2010. The role of incubator interactions in assisting new ventures. Technovation 30 (3), 155-167.

Sherman, H., Chappell, D.S., 1998. Methodological challenges in evaluating business incubator outcomes. Economic Development Quarterly 12 (4), 313-321.

Singh, J.V., Tucker, D.J., House, R.J., 1986. Organizational legitimacy and the liability of newness. Administrative Science Quarterly 31 (2), 171-193.

Smilor, R.W., Gill, M.D.J., 1986. The New Business Incubator: Linking Talent, Technology, Capital, and Know-How. Lexington Books, Toronto.

Tornatzky, L., Sherman, H., Adkins, D., 2003. Incubating Technology Businesses: A National Benchmarking Study. National Business Incubation Association, Athens, Ohio.

UKBI, 2007. What is Business Incubation? Retrieved 28.05.2008, from <http:// www.ukbi.co.uk >.

Vohora, A., Wright, M., Lockett, A., 2004. Critical junctures in the development of university high-tech spinout companies. Research Policy 33 (1), 147-175.

von Zedtwitz, M., Grimaldi, R., 2006. Are service profiles incubator-specific? Results from an empirical investigation in Italy. The Journal of Technology Transfer 31 (4), 459-468.

Yin, R., 2009. Case Study Research: Design and Methods, 4th ed. Sage Publications, Thousand Oaks.

Yli-Renko, H., Autio, E., Sapienza, H.J., 2001. Social capital, knowledge acquisition, and knowledge exploitation in young technology-based firms. Strategic Management Journal 22 (6/7), 587-613.

Zahra, S.A., Sapienza, H.J., Davidsson, P., 2006. Entrepreneurship and dynamic capabilities: a review, model and research agenda. Journal of Management Studies 43 (4), 917-955.

Zhao, L., Aram, J.D., 1995. Networking and growth of young technology-intensive ventures in China. Journal of Business Venturing 10 (5), 349-370. 